\title{
Colóquio de San Remo
}

P or ocasião do XI Congresso Internacional de Ciências Administrativas, realizado em Wiesbaden, Alemanha, em setembro de 1959, reuniu-se o Conselho de Administração do IICA, que, entre outras deliberações, tomou a de modificar, parcialmente, a forma das reunióes anuais que são realizadas nos intervalos dos Congressos trienais.

É que, na opinião do Conselho, está provado que as mesas-redondas, realizadas nos dois anos correspondentes ao intervalo entre os Congressos, vinham-se transformando em pequenos congressos, dado o grande número de participantes. Eram assim, formas de reunião muito trabalhosas, requerendo anualmente o preparo de documentação pràticamente idêntica à dos congressos.

Por essas razões, decidiu o Conselho que em 1960 a reunião tome a forma de «colóquio», havendo em 1961 uma mesa-redonda mas com participantes convidados.

Tomarão parte no Colóquio apenas os membros do Conselho de Administração, os membros dos Comitês Permanentes, os membros das Seç̃os Nacionais e os representantes dos Estados membros. Assim, em vez de 200 ou 300 participantes, apenas 100 são esperados.

O Colóquio de 1960 será realizado em San Remo, sob os auspícios do govêrno municipal no periodo de 22 a 25 de junho.

Serão focalizados os seguintes temas:

— «Assistência Técnica em Administração Pública - Lições de experiência e aperfeiçoamentos possiveis».

— «Relações Públicas em Administração».

— «Organização governamental para desenvolvimento econômico a longo prazo».

Devido ao caráter preparatório da reunião, não foram solicitados relatórios aos diversos países.

Para cada tema será designado um relator, que deverá fazer uma exposição ampla do tema, resumir a documentação existente e trabalhos feitos por outras organizações sôbre o mesmo tema e propor um questionário detalhado que servirá de base aos trabalhos posteriores do IICA. 
Os questionários que forem preparados pelos relatores, depois de discutidos, tomarão forma definitiva e serão distribuidos pela IICA aos seus Estados membros e demais países em que haja Seções Nacionais ou correspondentes.

O IBCA já solicitou ao Banco Nacional do Desenvolvimento Econômico, ao Departamento Administrativo do Serviço Público e à Comissão Nacional de Assistência Técnica, do Ministério das Relações Exteriores, informações e relatórios referentes aos temas a serem debatidos.

Com essa medida, o Brasil estará em condições de se apresentar em San Remo com elementos seguros para informar os relatores e fornecer dados para os questionários.

Além das reuniões de estudos, haverá uma sessão do Conselho de Administração e reuniões das Comissões Permanentes do IICA. 